IFN Working Paper No. 847, 2010

\title{
The CFO's Information Challenge in Managing Macroeconomic Risk
}

Lars Oxelheim, Clas Wihlborg and

Marcus Thorsheim 


\title{
The CFO's information challenge in managing macroeconomic risk
}

\author{
Lars Oxelheim \\ Lund Institute of Economic Research \\ Lund University, P.O. Box 7080, 22007 Lund, Sweden \\ E-mail: Lars.Oxelheim@fek.lu.se \\ and \\ The Research Institute of Industrial Economics \\ P.O Box 55665, SE-10215 Stockholm, Sweden \\ E-mail: Lars.Oxelheim@ifn.se
}

Clas Wihlborg

Clas Wihlborg, Argyros School of Business and Economics,

Chapman University, Orange, CA 92866

E-mail: Wihlborg@chapman.edu

Marcus Thorsheim

Lund Institute of Economic Research

Lund University, P.O. Box 7080, 22007 Lund, Sweden

E-mail: Marcus.Thorsheim@fek.lu.se

August 19, 2010

\begin{abstract}
In this chapter we examine the role of the CFO in setting risk management strategy with respect to macroeconomic risk, in particular, and we consider the information requirements for setting a strategy that is consistent with corporate objectives. We argue that macroeconomic risk management requires a broad approach encompassing financial, operational and strategic considerations. Furthermore, several interdependent sources of risk in the macroeconomic environment must be taken into account. Once this interdependence among, for example, exchange rates, interest rates and inflation are taken into account macroeconomic risk management can be considered a relatively self-contained aspect of Integrated Risk Management (IRM) provided relevant information is available to management. Financial risk management cannot be considered a self-contained part of macroeconomic risk management, however, since value increasing investments in flexibility of business operations affect corporate exposure and make it uncertain.
\end{abstract}

Key words: risk management strategy, macroeconomic risk, integrated risk management, chief financial officer, information needs, corporate strategy, financial risk, real options,

JEL: F23, G01, G32, G34, M21

Forthcoming in Fabich, M., L. Firnkorn, U. Hommel and E. Schellenberg (eds), The Strategic CFO - Creating Value in a Dynamic Market Environment. Heidelberg: Springer Verlag

Financial support from the NASDAQ OMX Nordic Foundation for Lars Oxelheim is gratefully acknowledged. 


\section{Introduction}

The sub-prime loan crisis and subsequent economic and financial turmoil have directed the spotlight on the key-role of the chief financial officer (CFO) in developing a comprehensive risk management strategy. The turmoil has also focused attention on the link between corporate- and risk management strategies, and, in particular, the CFO's role as member of the top level management team.

In this chapter we examine the role of the CFO in setting risk management strategy with respect to macroeconomic risk, in particular, and we consider the information requirements for setting a strategy that is consistent with corporate objectives. We argue that macroeconomic risk management requires a broad approach encompassing financial, operational and strategic considerations. Furthermore, several interdependent sources of risk in the macroeconomic environment must be taken into account. Once this interdependence among, for example, exchange rates, interest rates and inflation are taken into account macroeconomic risk management can be considered a relatively self-contained aspect of Integrated Risk Management (IRM) provided relevant information is available to management.

Rapidly increasing economic and financial integration has made more or less all firms exposed to events in the global economic arena. This exposure creates risk as well as opportunities. Risk management strategies must be shaped with an awareness of their potential contributions as well as costs relative to corporate objectives. Relevant, up to date information is not always readily available to financial managers. Thus, the feasibility of risk management strategies may be constrained by the availability of information and the interaction between the finance and other divisions. The evaluation of risk management strategies and the performance of the finance division present additional information problems.

The responsibility of the CFO has gradually been extended to encompass strategic aspects (Mian 2001; CFO Research Service 2005; Accenture 2007; CFO Research Service 2007). The trend towards viewing financial polices as inseparable from corporate strategy has become evident in the risk management literature. "Holistic" risk management approaches, such as IRM and enterprise risk management (ERM), include a wide variety of strategic, 
operational and financial decisions among the instruments for managing risk (see Shapiro and Titman 1986; Miller 1992; Miller 1998; Meulbroek 2002; Nocco and Stulz 2006).

Traditional approaches to managing, for example, exchange rate risk focused on transaction- and translation exposures and relied on accounting data to a great extent. Effects of exchange rate changes on cash flows through price and sales effects were rarely considered (Miller 1998; Oxelheim and Wihlborg 2008). Traditional approaches to managing interest rate risk were similarly limited to managing risk of interest rate linked financial positions. Interest rate changes may affect corporate cash flows through non-financial channels as well. Using these traditional measures of exchange-and interest rate exposures, hedging activities were performed tactically rather than strategically employing financial instruments directly linked to these exposures. Any link between exchange rates and interest rates or any other macroeconomic variable were not taken into account. The exposure of commercial cash flows to these variables was not within the information set of the risk managers.

IRM is a comprehensive framework for managing risk exposures and includes the identification, measurement and evaluation of all kinds of risk and the possible linkages among them. Meulbroek (2002) divides total risk into seven categories; financial-, product market-, operational-, input-, tax-, regulatory- and legal risk. An IRM strategy utilizes financial instruments, insurance, contractual relations with stakeholders, operational adjustment, capital structure as well strategic adjustment.

Research is short of studies supporting the notion of IRM being superior to traditional risk management in value creation in non-financial firms (see Hoyt and Liebenberg 2009). Some researchers claim that the firm-wide implementation of IRM is in itself a source of value, due to the increasing awareness of risk exposures throughout a firm (Nocco and Stulz 2006). On the other hand, many studies accentuate the problems surrounding the implementation. Meulbroek (2002) emphasizes the challenges related to the coordination between different parts of a firm. Nocco and Stulz (2006) stress the difficulties in communicating the strategy throughout a firm. CFO Research Service (2002) show that inadequate information systems are one of the main barriers to implementing a strategic risk management program. A survey from 2005 shows that CFOs have insufficient information to support strategic decision-making (CFO Research Service 2005). Hence, prior research indicates that the information issue is critical for more comprehensive risk management strategies to create value. 
Macroeconomic risk analysis as defined in this chapter takes its starting point in macroeconomic sources of risk and the broad impact of these sources on financial-, product market-, operational and input exposures. We argue that a firm must approach the macroeconomic exposures through a comprehensive framework, more specifically the MUST-analysis, recognizing the firm wide effects of macroeconomic variables as well as the interdependence among them. The MUST-analysis as developed in Oxelheim and Wihlborg (2008) measures the exposure of commercial operations in a multivariate framework in order to obtain a benchmark for management of financial positions. Risk-management incorporates adjustment of commercial operations in order to, for example, create flexibility (real options) as well as of financial positions including capital structure. The risk management strategy in MUST is subordinated to corporate strategy and objectives. The information required for implementation of a macroeconomic risk strategy will be discussed below.

The MUST-analysis also provides management with information of value for strategic analysis. A firm's cash flow can be divided into a macroeconomic and an "intrinsic" component that reflects the firm's competitiveness based on its strategic assets. (see Oxelheim and Wihlborg 2008).

The rest of the chapter is organized as follows. In section 2 we review the role of the CFO within the decision making structure of a firm. In section 3 we define the macroeconomic environment of a firm and, thereby, the identification of macroeconomic exposures as a relatively self-contained subset of a firm's total risk-exposure. In section 4 we discuss how a risk-management strategy can be formulated. Information requirements associated with different strategies and their evaluation are discussed in section 5. Concluding remarks follow in section 6.

\section{The CFO and levels of decision-making}

The CFO is responsible for formulating and implementing policy decisions linked to a firm's financial system. CFO's field of responsibility encompasses a number of functions, as financial reporting, cost management, budgeting, financing, risk management, investment management, treasury and tax management, and financial strategy.

Concerning financial reporting, i.e. internal and external accounting, the CFO is in general responsible for supervising the process of making financial reports and for the external communication of the firm's financial strategy and decisions (Mian 2001). Besides 
financial reporting, and to some extent cost management and budgeting, the majority of the functions in the financial system relates to the treasury side. The treasury components are highly interconnected, which from a decision-making point of view emphasizes the importance of having an adequate information system in place. This issue becomes even more important in large firms where the operational implementation of decisions related to financial policies is carried out by several departments on different levels.

In addition to the primary responsibility of the financial system, several surveys show that the CFO to an increasing extent is involved in the development and implementation of a firm's commercial strategy (CFO Research Service 2005; Accenture 2007; CFO Research Service 2007). In a survey conducted 2007 by Accenture $83 \%$ of the CFOs indicate that they are active in formulating corporate strategies and $95 \%$ of the CFO's are involved in the implementation process. The financial and corporate strategies should be seen as interconnected. An IRM approach requires the CFO to be involved in both the financial- and commercial strategy since the firm's commercial strategy represents an explicit tool for managing risk exposures in IRM.

Corporate decision-making from a risk management perspective can be illustrated as in Figure 1 from Oxelheim and Wihlborg (2008). There are three levels of decision-making; top management level, tactical level and operational level. Top management - the board of directors and the chief executive officer (CEO) - formulates the general financial policies of a firm along with the commercial strategy. Even if the CFO's formal responsibility lies primarily on the tactical level, the role still incorporates an advisory function on the top level. From a risk management point of view an important consideration is that overall firm objectives determined on the top level and specific risk management objectives determined on the tactical level are consistent. One way top management can achieve consistency is through its responsibility for designing appropriate compensation schemes and for performance evaluation of the tactical level, including the CFO, head of sales etc.

The CFO's responsibility on the tactical level is to make the overall strategies operational and to manage their implementation. From the CFO's perspective this involves formulating an operational risk management strategy in accordance with the general strategy set by top level management. More specifically, determining risk levels, picking the most convenient methods and tools, and actively manage exposures. The operational level is accountable for carrying out the tasks inherent in the operational strategy formulated by the CFO, such as timing of contracts, managing bank connections and liquidity. 
Figure 1. Levels of decision-making in risk management

\begin{tabular}{|c|c|c|c|}
\hline Level & Title/individuals & $\begin{array}{c}\text { Example of decision } \\
\text { choice }\end{array}$ & Evaluation \\
\hline $\begin{array}{l}\text { Top level } \\
\text { management }\end{array}$ & $\begin{array}{l}\text { Managing director (CEO) } \\
\text { and Board of Directors. }\end{array}$ & $\begin{array}{l}\text { Formulation of risk } \\
\text { management strategy. }\end{array}$ & $\begin{array}{l}\text { Self-evaluation } \\
\text { and market } \\
\text { monitoring. }\end{array}$ \\
\hline Tactical level & $\begin{array}{l}\text { CFO, Chief risk officer } \\
(\mathrm{CRO}) . \text { Head of Sales and } \\
\text { other division heads. }\end{array}$ & $\begin{array}{l}\text { Implementation of } \\
\text { strategy, decisions on risk } \\
\text { levels. Choice of type of } \\
\text { risk management tools. }\end{array}$ & $\begin{array}{l}\text { Level and } \\
\text { variance of cash } \\
\text { flows. Cost of } \\
\text { financing. }\end{array}$ \\
\hline $\begin{array}{l}\text { Operational } \\
\text { level }\end{array}$ & Treasurer, controller etc. & $\begin{array}{l}\text { Timing of forward } \\
\text { contracts and options. } \\
\text { Minimize transactions } \\
\text { costs }\end{array}$ & $\begin{array}{l}\text { Minimum cost of } \\
\text { obtaining desired } \\
\text { contracts. }\end{array}$ \\
\hline
\end{tabular}

An important aspect to consider in Figure 1 is the information flow between top management and the tactical level, as well as between departments and individuals on the tactical and operational level. The operational success of a risk management strategy is contingent on the distribution of responsibility, incentives of decision makers and the adequacy of the information system supporting the chosen strategy. The responsibility for commercial and financial decisions has to be clearly defined and allocated on the tactical level. For example, if the head of sales is responsible for adjusting the product mix on different markets, an information channel between the CFO and head of sales must exist since a change in the product mix may translate into a change in commercial exposure and, thereby, the exposure and hedging targets for financial positions.

The interconnection between commercial and financial strategies becomes apparent in an IRM strategy and in the MUST-analysis. In a traditional risk management strategy it is sufficient with an information system supplying the CFO with the information needed to 
implement the strategy more or less in isolation from the corporate strategy, whereas the information need becomes more complex in the more comprehensive approach discussed in this chapter. The reason is that the commercial strategy, capital structure and financial risk management interact to determine risk exposures.

\section{The macroeconomic environment of the firm}

Competition benchmarks are to a large extent established on an international basis and management must be able to evaluate the interplay between the firm and its macroeconomic environment. This is critical since the macroeconomic development may have a considerable impact on corporate cash flows, and two firms with similar strategies may experience substantial differences in profitability due to divergent macroeconomic exposures. It is the CFO's task to identify the macroeconomic context and its firm-specific impact.

Figure 2 exhibits the link between a firm's macroeconomic environment and its cash flows. The figure provides a point of departure for further discussion. In column 1 the origin of macroeconomic uncertainty is divided into domestic and foreign policy and non-policy macroeconomic shocks. In addition to the macro-related sources of disruption, firm- and industry-specific factors represent sources of uncertainty. The latter sources of uncertainty affect a firm's competitiveness and must be approached with strategies and tools that differ from applying to macroeconomic uncertainty.

Macroeconomic disturbances can, as showed in column 2, be divided into two categories dependent on their characteristics, more specifically monetary or aggregate real. One way to analyze cash flow effects of the different types of macroeconomic shocks would be to identify effects of these shocks on corporate cash flows. However, this is difficult to accomplish for several reasons. First, policy interventions in response to shocks, described in column 3, may distort the effects of the initial shock. Second, interventions can be either of monetary and/or fiscal character, as well as industrial and trade related. Third, and perhaps most important, it takes time to observe the nature of macroeconomic shocks even for the analyst who has a specific model to rely on. The task is made worse by uncertainty about the appropriate macroeconomic model.

Instead of linking shocks to corporate cash flows the analyst can focus on identification of relationships between market price variables shown in column 4 and cash flows. Changes in market price variables such as exchange rates, interest rates and inflation 
rates reflect changes in the macroeconomic environment and they are observable with little lag. Thus, the firm that can identify the effects of price variables in column 4 on cash flows in column 5. Thereby, macroeconomic exposures have been measured. Jointly these exposures constitute the exposure to macroeconomic shocks in column 1. Using exposure coefficients for, for example, exchange rates, interest rates and inflation, in combination with a model linking fundamental shocks and price variables, it is possible to create scenarios for analysis of the effects on cash flows of various macroeconomic shocks.

Figure 2. Macroeconomic environment and the cash flow effect from shocks

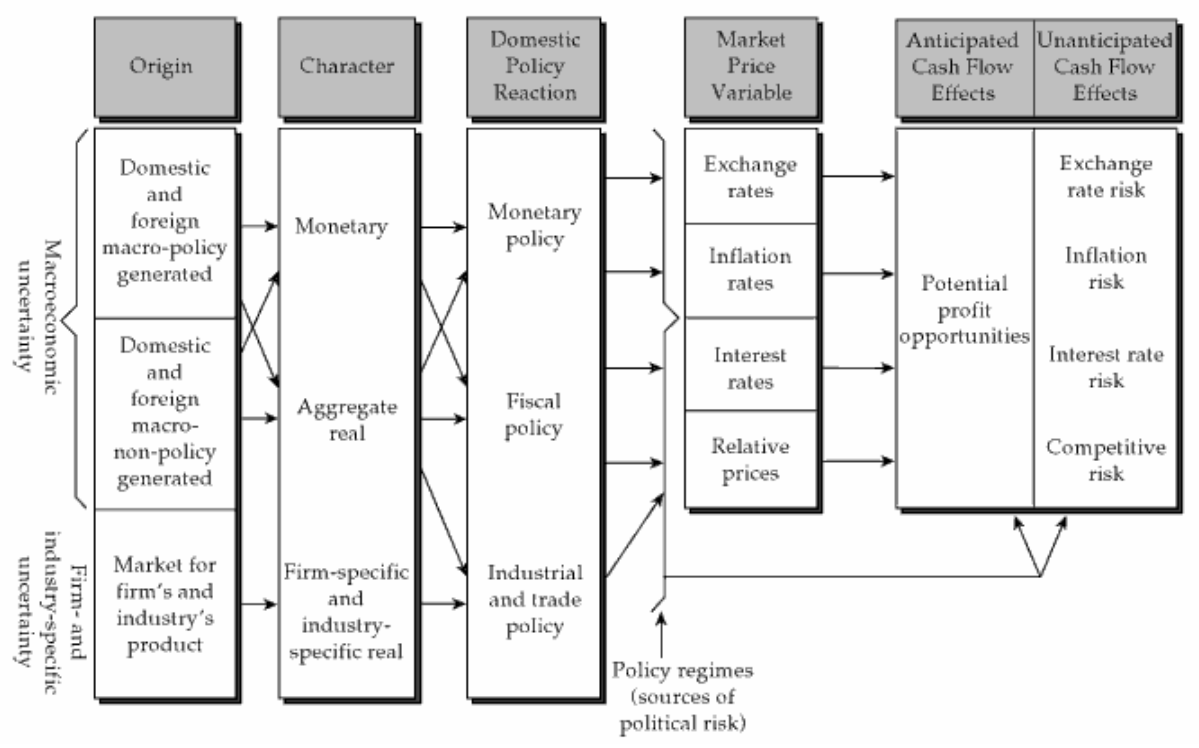

Source: Oxelheim and Wihlborg (2008)

When exposures to exchange rates, interest rates and inflation rates are analyzed it is necessary to consider that these variables tend to adjust simultaneously to underlying shocks. Thus, the price variables tend to be correlated. For this reason, Oxelheim and Wihlborg (2008) suggest that a multivariate framework is required to identify exposure coefficients. If a univariate framework is used it is possible that, for example, exchange rate exposure and inflation exposure overlap since these variables often are correlated according to Purchasing Power Parity (PPP) theory. Similarly, interest rate exposure and exchange rate exposure may overlap since these variables tend to be linked by international capital flows. The responsiveness of these flows to domestic and foreign interest rates is reflected in the strength of (uncovered) interest rate parity, also called International Fisher Parity (IFP). 
Once macroeconomic exposures have been identified the MUST-analysis framework provides a tool for analysis of the relationship between exposure of commercial operations and exposure of financial positions. Financial positions can be adjusted with the exposure of commercial operations as a benchmark for minimizing total exposure. Alternatively, commercial operations can be adjusted to reduce exposure or enhance the flexibility of operations to changes in the environment. Finally, capital structure can be adjusted in order to have a sufficient equity capital to withstand macroeconomic uncertainty. The specific approach to managing exposure depends on the firm's risk management strategy.

Figure 2 helps us to grasp the complexity of a CFO's responsibility for the risk management strategy and for the information flows between different levels in a firm. First, the CFO is responsible for defining the macroeconomic context and assessing the different dimensions in the model in order to identify and analyze the firm-specific exposure. Second, identification of commercial exposure may require substantial input from heads of sales and purchasing. Third, the CFO must interpret and communicate the outcome to the top level management which then serves as the foundation for formulating the overall strategy. Fourth, the strategy may include objectives and instruments with respect to both financial positions and commercial operations. The role of the CFO as adviser on corporate strategy was emphasized in the above mentioned surveys. The view presented here implies not only the CFO's role as advisor but also the interdependence between the CFO's area of responsibility and other areas of responsibility on the operational side.

\section{Formulation of a risk management strategy}

The general strategy formulated by the top management in terms of objectives of risk management only serves as guidance for decisions on the tactical and operational levels. An operational strategy has to be formulated on the tactical level along with information requirements and the organization of risk-management. As emphasized by Oxelheim and Wihlborg (2008) the operational strategy should be based on the following four aspects of the firm's more general strategy and objective; target variable, time horizon, risk attitude and management's view on market relationships.

\subsection{Target variable}


The choice of variable for risk management must be consistent with the overall strategy and firm objectives expressed either in accounting or economic terms. Variables based on nominal accounting are in general weak determinants of shareholder value, even if equity markets devote much of their attention to reported earnings.

Assuming that an economic objective is chosen, the potential target variables are economic value, market value, profits or cash flows. Whether a firm should target market value or economic value is a question of belief in market efficiency. A firm's intrinsic, or economic value, should in a long-term perspective equal its market value. A firm's time horizon is in part a function of the target variable.

\subsection{Time horizon}

Targeting economic value or cash flows is a question of time perspective since these two measures converge through a firm's cost of capital. We argue that most firms benefit from an extended time horizon and that the main reason to manage macroeconomic exposures in a short-term perspective is the risk of encountering liquidity constraints (Froot et al 1994). A firm experiencing financial distress or liquidity constraints need to manage its exposures on a short-term basis to avoid incurring losses due unanticipated cash flow changes.

Another aspect to consider in the choice of time horizon is the flexibility in commercial operations and the statistical phenomena of mean reversion. Long-term exposures are less of a concern in an IRM strategy since firms with inherent flexibility can utilize strategic real options to offset long-term exposures. We return to flexibility and real options below.

Efficiency of pricing in goods and financial markets also affect the time horizon of risk management. Over periods sufficiently long for PPP and IFP relationships to hold there are no profit opportunities in price and interest rate differentials between countries.

\subsection{Risk attitude}

Risk attitude along with the management's view on market relationships makes up the foundation of our operational risk management strategies. Risk attitude is the main determinant in the decision of whether a firm should manage its risk exposures or not. A riskneutral firm does not trade-off return and risk. It always tries to maximize expected cash flows or value. A risk-averse firm is prepared to sacrifice return in favor of a lower variance of cash flows or value. 
The operational choice between risk-aversion and risk-neutrality must be determined considering the expected loss from an unanticipated macroeconomic outcome. A highly exposed firm that is likely to incur significant bankruptcy costs or costs of liquidity constraints in case of lower tail outcomes, should consider a risk-averse approach while a firm with low costs associated with bankruptcy or lack of liquidity could choose a risk-neutral attitude.

\subsection{Management's view on market price relationships}

It was noted above that the time horizon over which PPP holds affects the time horizon over which exchange rate risk is a concern. In this subsection we consider three financial markets price relationships that affect the opportunities and costs of managing currency denominations and maturities of financial positions and, therefore, the trade off between risk and return in financial markets.

The first financial market relationship that requires evaluation is International Fisher Parity (IFP) implying that there are no expected profit opportunities of shifting financial positions among currencies. The second relationship is the Expectations Hypothesis (EH) for the yield structure across maturities of financial positions in a certain currency. EH implies that there are no profit opportunities from shifting financial positions among assets or liabilities with different maturities. A long-term interest rate is simply an average of expected short-term interest rates over time.

The third market relationship affecting risk management on financial positions is Fisher Parity (FP) which implies that the expected real interest rate is independent of expected inflation, and that the nominal interest rate is simply the sum of these two components. If FP holds the maturity structure can be managed with respect to either real interest rate risk or inflation risk. If the relationship does not hold, inflation and real interest rates on financial instruments will be correlated. Thereby, real interest rate exposure and inflation exposure of financial instruments are not independent.

Risk attitude and the CFO's view the three financial market relationships discussed above jointly determine important aspects of a risk management strategy that may satisfy corporate objectives. Figure 3 illustrates how strategies with respect to macroeconomic sources of risk can be classified as "Laissez-faire", minimization of exposure, aggressive and selective hedging based on risk attitude and perception about efficiency of market pricing. We distinguish between strategies with respect to exchange rate exposure and interest rate 
exposure since differences can exist between efficiency of domestic- and international financial markets. It is also assumed that commercial exposures are given over a specific time horizon. Thereby we exclude investments in flexibility (real options) of commercial operations as a risk management tool. Real options are discussed below in the next subsection 4.5. For simplicity we assume that inflation exposures are managed in other markets in order to focus on exchange rate and interest rate risk.

The upper four boxes in Figure 3 represent strategies for managing exchange rate exposure. "Laissez-faire" is viable strategy for a risk-neutral firm that believes that IFP holds. Do nothing about currency denomination is viable because there are no profit opportunities in the international financial markets and the firm is not concerned with cash flow variance. The upside of this strategy is that a firm can focus on its core activities, which can be a valuable feature. A CFO of a risk-neutral firm assuming that IFP does not hold would choose an aggressive strategy in Figure 3 because the CFO believes that there are profit opportunities based on forecasting while not having to worry about risk.

A CFO of a risk-averse firm who believes that IFP holds minimizes macroeconomic exposure for the firm by using financial positions to offset the exposure of commercial operations. Managing exposures of a risk-averse firm under the assumption of IFP is a relatively simple task. The complexity increases as soon as the CFO perceives that there are profit opportunities in financial markets. A selective hedging strategy in Figure 3 would reflect a desired trade-off between risk and return on financial positions. Ideally the trade-off would be determined on the top management level and translated into a selective hedging strategy by the CFO. This is far from a mechanical process and it requires coordination of all corporate financial positions. It involves a great deal of uncertainty due to the human factors as well. For example, hubris with respect to forecasting ability is a common affliction. Internal incentives and rewards on the operational level are also important.

The lower part of Figure 3 refers to the domestic financial positions strategies to manage interest rate exposure by adjusting the maturity structure based on a benchmark provided by the interest rate exposure of commercial operations. The determination of "laissez-faire", minimize exposure, aggressive and selective hedging strategies with respect to interest rate risk is analogous to the determination of strategy with respect to exchange rate risk except that it is perceptions about EH instead of IFP that must be considered. Deviations from EH implies that there are potential profit opportunities in the adjustment of maturity 
structure. In addition to $\mathrm{EH}$, we also consider perceptions about FP in interest rate risk management in Figure 3. This parity implies that real interest rate movements are independent

Figure 3. Comprehensive macroeconomic risk management strategies

\begin{tabular}{|c|c|c|c|c|}
\hline \multirow[t]{2}{*}{ Market } & \multicolumn{2}{|c|}{$\begin{array}{l}\text { Management's } \\
\text { view on the } \\
\text { market }\end{array}$} & \multicolumn{2}{|c|}{ Risk attitude } \\
\hline & & & Risk-neutral & Risk-averse \\
\hline \multirow[t]{2}{*}{$\begin{array}{l}\text { International } \\
\text { financial } \\
\text { markets }\end{array}$} & \multicolumn{2}{|l|}{ IFP } & $\begin{array}{l}\text { "Laissez faire" with } \\
\text { respect to currency } \\
\text { denomination }\end{array}$ & $\begin{array}{l}\text { Minimize exposure to } \\
\text { exchange rate uncertainty }\end{array}$ \\
\hline & \multicolumn{2}{|c|}{ Non-IFP } & $\begin{array}{l}\text { Aggressive strategy with } \\
\text { respect to currency } \\
\text { denomination }\end{array}$ & $\begin{array}{l}\text { Selective hedging trading of } \\
\text { risk-return }\end{array}$ \\
\hline \multirow[t]{4}{*}{$\begin{array}{l}\text { Domestic } \\
\text { bond } \\
\text { markets }\end{array}$} & $\mathrm{EH}$ & $\overline{\mathrm{FP}}$ & $\begin{array}{l}\text { Laissez faire with respect } \\
\text { to maturity structure and } \\
\text { interest rate adjustability }\end{array}$ & $\begin{array}{l}\text { Minimize exposure to real } \\
\text { interest rate exposure }\end{array}$ \\
\hline & & $\begin{array}{l}\text { Non- } \\
\text { FP }\end{array}$ & & $\begin{array}{l}\text { Minimize exposure } \\
\text { considering real interest rate } \\
\text { exposure linkage with } \\
\text { inflation }\end{array}$ \\
\hline & $\begin{array}{l}\text { Non- } \\
\text { EH }\end{array}$ & $\mathrm{FP}$ & $\begin{array}{l}\text { Aggressive strategy with } \\
\text { respect to maturity } \\
\text { structure and interest rate } \\
\text { adjustability }\end{array}$ & $\begin{array}{l}\text { Selective hedging of real } \\
\text { interest rate exposure }\end{array}$ \\
\hline & & $\begin{array}{l}\text { Non- } \\
\text { FP }\end{array}$ & & $\begin{array}{l}\text { Selective hedging considering } \\
\text { real interest rate linkage with } \\
\text { inflation }\end{array}$ \\
\hline
\end{tabular}


Note: Laissez-faire implies that currency denomination and maturity structure are determines entirely by the most favorable transaction fees and spreads offered to the specific firm in the market.

Source: Oxelheim and Wihlborg (2008)

of inflation movements. In this case, interest rate risk management can be oriented towards either inflation risk or real interest rate risk while, if IFP does not hold, the correlation between inflation rates and interest rates must be considered in order to effectively manage exposures. The complexity of risk management is increased if FP cannot be assumed.

\subsection{Management of commercial operations; Flexibility and real options}

The exposure management strategies discussed so far have been based on the assumption that the exposure of commercial operations is given and that financial positions are taken to reduce the total exposure if so desired. There is an obvious substitutability between hedging with financial contracts and adjustment of commercial operations, however. Over time horizons when there is adjustability of commercial operations in different dimensions, risk management by means of financial positions may not be the best strategy for dealing with exposure. We elaborate on such instruments here.

An important aspect of these instruments is that they often can be thought of as "real" options that enable a firm to both reduce exposure and increase expected profits. Thus, they are not only substitutes for financial instruments but complements as well, and they should be considered by all firms regardless of risk attitude. Deviations from PPP can be long lasting and affect the profitability of a firm's operations to such an extent that the viability of the operations is threatened by such factors as low domestic currency prices on exported outputs, high costs of imported inputs, or lack of competitiveness in the market relative to foreign producers. Over longer time horizons when PPP holds, there is no exchange rate risk but there may be exposure of commercial operations owing to uncertainty about relative prices among outputs and inputs. In general, exposure to price differences between outputs and inputs can be managed by adjustment of commercial operations in different dimensions. Such adjustment is generally costly, however. Principles for managing such exposure have been developed theoretically by applying the theory of option pricing. The ability to move a production site from one country to another, to shift from a supplier in one country to a supplier in another country, to abandon a market where losses mount, and to enter a new 
market where profits are expected are all "options" that can be exercised at a cost. By creating flexibility of operations in different dimensions, these costs can be reduced, enabling the firm to better take advantage of profit opportunities. Thus, exposure management by means of commercial operations affects the firm's profitability as well as its exposure to real exchange rate changes and relative price shifts (Capel 1997).

The multinational firm with production units in more than one country can shift production from one country to another (if spare capacity exists), when relative labor costs change as a result of exchange rate changes (see Kogut and Kulatilaka 1994). In many industries, the hindrances to such shifts are substantial either because of non-standardization of products or because of labor relations in producing units. A more valuable option for many firms would be to expand purchases of inputs from suppliers in countries with favorable real exchange rates and reduce purchases from others.

Abandoning markets where losses are made is also associated with costs, if the firm hopes to reenter in the future. Customer relations may be hurt and there are costs associated with reentry and regaining market share (Oxelheim et al, 1990). The costs of entering a market the first time are likely to be even higher. Thus, to either abandon or enter a new market is generally not worthwhile for small relative price changes even if a conventional project evaluation would indicate that the changes are profitable. The reason why conventional project evaluation techniques fail to give the correct signals is that they do not take into account that, under uncertainty, reversals of decisions may become necessary and there are costs specifically related to these reversals. Thus, when there is uncertainty about real exchange rates and relative prices there is "a band of inaction"; within this band current operations continue unchanged even if losses occur.

The "options" associated with adjustability of commercial operations are more valuable as the uncertainty about real exchange rates and relative prices increases. They are also more valuable if the irreversible costs of changes can be reduced. Thus, high uncertainty makes flexibility or adjustability more valuable because it enables the firm to take advantage of profit opportunities in commercial operations. For example, spreading input purchases among suppliers in different countries reduces the costs of expanding these purchases in the country with the most favorable exchange rates.

The firm's rule for responses to changes in exchange rates, interest rates, and other sources of cost changes constitute the firm's pricing strategy. Commercial exposure is strongly influenced by this strategy. Increased uncertainty in exchange rates and the 
macroeconomic environment can make it worthwhile to change the pricing strategy in order to allow greater flexibility and greater pass-through. The benefits of adjusting prices to levels that lead to higher short-run profits under different circumstances must be weighed against the costs of not being able to offer customers a stable price. To some extent the price adjustment to changes in, for example, exchange rates can be predetermined in contracts. Trade credit terms can also include payment adjustment in response to inflation and exchange rate changes. The use of such adjustment clauses is not unusual (see Oxelheim et al 1990).

The general implication of this discussion is that flexibility and adjustability of operations and pricing are exposure management tools which, to be worthwhile, require a minimum degree of uncertainty about future prices. If uncertainty is high, however, there are reasons to invest in the ability to adjust operations even in the short run, thereby reducing the need for exposure management by financial positioning and increasing expected profits. Over the longer term the costs of adjustability can be diminished, because options are "built in" by the need to replace assets and individuals. Over such horizons, exposure management by adjustment of financial positions is superfluous (see Trigeorgis 1996; Amran and Kulatilaka 1999; Copeland and Antikarov 2001).

\section{Exposure strategies and information requirements}

In this section we first consider the information requirements associated with the financial risk management strategies described in Figure 3. Thereafter, we turn to the additional requirements associated with flexibility of commercial operations. Finally we turn to information requirements associated with evaluation and organization of risk management.

\subsection{Financial risk management strategy and information requirements}

Besides the operational variables and in particularly, risk attitude and market price relationships, an exposure strategy has to be built on an adequate information system supporting the strategic approach. An exposure strategy undermined by an insufficient information supply may create more costs than benefits. In Figure 4 we outline the information requirements for the strategies discussed in Figure 3.

Risk neutral strategies are relatively straightforward and the information requirements are in return very limited. Implementing and exploiting a laissez-faire strategy requires information about transaction costs; bid-ask spreads and fees, but forecasting and estimation of variances and covariances are not needed since currency denomination and maturities are 
found irrelevant. If the IFP and/or EH do not hold then forecasting profit opportunities is required to implement an aggressive strategy but the risk neutral firm does not need exposure and risk information.

Risk management strategies based on a risk-averse attitude are both more complex and in need of more information. A "minimize variance" strategy requires exposure coefficients (multivariate exposure coefficients from the MUST-analysis) concerning commercial exposures and financial positions even if market relationships are supposed to hold. This information requirement based on the perception that markets do not allow profit opportunities is still modest relative to the information needed to implement a selective hedging strategy efficiently.

Selective hedging is based on risk-aversion and the belief of the CFO that forecasting of exchange rates and interest rates offers profit opportunities. Information with respect to forecasting must be complemented with variances and co-variances for financial positions. In practice, most CFOs do not believe in the parities hold and they typically state that they are risk averse. Thus, they are in need the most extensive information requirements specified in Figure 4. Not only do they need variance-covariance information, they also need information about how to trade off risk and return. Most often rules of thumb are used to set exposure limits with respect to risky currency positions and interest rate risk.

In spite of the formidable information requirements for the risk averse firm that rejects IFP and EH, we cannot exclude the value of employing a risk-averse strategy under the circumstances where adverse macroeconomic outcomes can seriously hurt a firm by increasing the probability of bankruptcy or the likelihood of liquidity constraints.

Information costs must be evaluated on strictly economic grounds. Thus, information costs must be compared with the expected gains from being able to trading off risk and return. Information costs can be evaluated relative to the expected costs of a worst case scenario outcome under a laissez-faire strategy. An additional consideration is that relatively complex strategies increase the likelihood of mismanagement if incentive structures are not appropriate and all the relevant information is not available.

\subsection{Real options and information implications}

Inclusion of real options in risk management increases complexity and information requirements. In addition to the requirements already described above, investments in flexibility of business operation need evaluation and once real options are in place the 
flexibility implies that the exposure of commercial operations may suddenly increase or decrease when an option is exercised. The latter consideration is relevant, in particular, when the firm only has a few "large" real options, such as the possibility of moving a large share of production from one location to another. In the more typical case the firm may have a large number of smaller options that kick in one by one when, for example, the exchange rate or the interest rate continues to move further away from "normal" levels. The exposure of commercial operations should be easier to predict for the firm with a large number of small real options. Without such information the benchmark exposure for financial management is uncertain.

Figure 4. Information requirements in comprehensive macroeconomic risk management strategies

\begin{tabular}{|c|c|c|c|c|}
\hline Market & \multicolumn{2}{|c|}{$\begin{array}{l}\text { Management's } \\
\text { view on the } \\
\text { market }\end{array}$} & \multicolumn{2}{|r|}{ Risk attitude } \\
\hline & & & Risk-neutral & Risk-averse \\
\hline \multirow[t]{2}{*}{$\begin{array}{l}\text { International } \\
\text { financial } \\
\text { markets }\end{array}$} & \multicolumn{2}{|l|}{ IFP } & - & $\begin{array}{l}\text { Commercial exposure to exchange } \\
\text { rates. } \\
\text { Exposure of financial positions. }\end{array}$ \\
\hline & \multicolumn{2}{|c|}{ Non-IFP } & $\begin{array}{l}\text { Exchange rate } \\
\text { forecasts (relative } \\
\text { to interest rate } \\
\text { differentials) }\end{array}$ & $\begin{array}{l}\text { Exposure coefficients (See Oxelheim } \\
\text { and Wihlborg 2008). } \\
\text { Exchange rate forecasts. } \\
\text { Variances and correlations among } \\
\text { currency positions. }\end{array}$ \\
\hline \multirow[t]{3}{*}{$\begin{array}{l}\text { Domestic } \\
\text { bond } \\
\text { markets }\end{array}$} & $\mathrm{EH}$ & $\mathrm{FP}$ & - & $\begin{array}{l}\text { Commercial and financial interest } \\
\text { rate exposure coefficients as above. }\end{array}$ \\
\hline & & $\begin{array}{l}\text { Non- } \\
\text { FP }\end{array}$ & - & $\begin{array}{l}\text { Interest rate exposure coefficients as } \\
\text { above. } \\
\text { Inflation exposure coefficients. } \\
\text { Interest rate-inflation correlations. }\end{array}$ \\
\hline & $\begin{array}{l}\text { Non- } \\
\text { EH }\end{array}$ & FP & $\begin{array}{l}\text { Interest rate } \\
\text { forecasts over the } \\
\text { maturity spectrum }\end{array}$ & $\begin{array}{l}\text { Interest rate exposures as above. } \\
\text { Interest rate forecasts. } \\
\text { Interest rate variances and } \\
\text { correlations across markets. }\end{array}$ \\
\hline
\end{tabular}




\begin{tabular}{|l|l|l|l|}
\hline & $\begin{array}{l}\text { Non- } \\
\text { FP }\end{array}$ & $\begin{array}{l}\text { Interest rate } \\
\text { forecasts over the } \\
\text { maturity spectrum }\end{array}$ & $\begin{array}{l}\text { Interest rate exposure coefficients as } \\
\text { above. } \\
\text { Inflation exposure coefficients. } \\
\text { Inflation forecasts. } \\
\text { Inflation variances and correlations } \\
\text { across maturities. } \\
\text { Inflation-interest rate correlations. }\end{array}$ \\
\hline
\end{tabular}

Note: All strategies require information about transaction-fees and bid-ask spreads in addition to the information listed above.

Source: Oxelheim and Wihlborg (2008)

Investments in real options also have a soft dimension since flexibility may be associated with costs in terms of relations with customers and suppliers.

The complexity of real option evaluation as well as exposure measurement when there is substantial flexibility implies that the perfect risk management strategy is unattainable for most firms. Simplifying assumptions and adjustments must be made. In our view, an appropriate way of running an IRM or MUST strategy without facing too much complexity and excessive information requirements is to estimate the exposures of commercial operations to macroeconomic variables and to use these exposures as benchmarks for financial positions. The uncertainty about the exposures does not mean that the estimates are useless. The exposures can be checked against knowledge about corporate operations and re-estimated on a quarterly or annual basis. If the firm undergoes important structural changes historical exposure data may lose relevance. In this case scenario analysis of exposure may be superior to statistical techniques.

\subsection{Evaluation of strategies and organization of risk management}

In this section we are concerned with the question whether the success of a risk management strategy can be evaluated ex post. From a shareholder perspective the ultimate objective of risk management would be to lower the firm's cost of capital but this cost is not directly observable and even if it can be observed it is difficult to identify effects of risk management.

There are serious pitfalls when evaluating risk management strategies ex post. These pitfalls can be the result of confusion between the risk concept that should be used from the perspective of general corporate objectives and the proxy for risk that can be measured. Risk is fundamentally an unobservable, forward looking variable. For ex post measurement the time horizon is an important factor and a source of misleading ex post measures of risk. 
Management's risk aversion may refer to uncertainty over a specific time horizon while risk is measured ex post as the variance of cash flows or value over a certain period. In this case, risk management is concerned with a conditional variance while the measured risk is an unconditional variance. Only if management's risk concern is the actual variance of cash flow or value is it possible to directly observe how risk management has performed.

The fact that risk is an expectation about the future implies that an observation of a large loss caused by, for example exchange rate changes, is not in itself evidence of a failure of measuring and managing risk. Nevertheless, arguments about failed risk management are often based on such "tail" observations.

The difficulty of evaluating risk management performance in hindsight implies that incentives of those involved in risk management must be considered carefully. For example, it is common that the CFO is evaluated based on the performance of the finance division as a profit center. If at the same time the CFO is the person deciding on risk management strategy in a risk averse corporation, there is an obvious conflict between the corporate objective and the incentives of the CFO.

Incentives of the CFO as well as of risk managers on the operational level are also linked to the organization of risk management. Organization affects information flows as well as incentives. An increased tendency towards centralization has been observed over the last few decades. This tendency can be explained by scale advantages when buying and selling currencies, opportunities for netting within a multidivisional firm, the scarcity of expertise on the local level in a multinational firm, advantages of centralized tax planning and avoidance of exchange controls on a centralized level. Centralization also enables the firm to take advantage of differences in financial transactions costs among markets.

In general centralization refers to decisions being made in entities with independent bankruptcy risk and independent access to credit markets, while decisions are made on lower levels without coordination in a decentralized organization. If the CFO of a consolidated multinational or multi-product firm is responsible for risk management then we can say that there is centralized responsibility. On the other hand, if the CFO is responsible for financial positions only while, for example, the head of sales conducts risk management with respect to commercial operations there is a degree of decentralization. Decentralization can also take the form that financial risk management responsibilities are assigned to local or product subsidiaries. 
An evaluation program for macroeconomic risk management should naturally include an evaluation of its organization and of performance relative to objectives with different degrees of centralization. Advantages of centralization may have to be traded off against advantages of decentralization in the form of information availability or motivation of managers on the operational level.

One way of achieving advantages of decentralization is to use internal prices in budgeting and performance evaluation. Internal exchange rates and interest rates can be set by the central finance function while local entities remain profit centers and evaluated at internal exchange rates and interest rates. Risk management objectives can be in conflict with profitability objectives, however, as noted above. Risk-taking responsibilities are, therefore, not easily decentralized in a firm with overall objectives that include the variance of cash flows or value. One way to resolve the dilemma is to let decentralized entities sell financial positions to the central finance function at internal prices while the central finance function takes responsibility for the consolidated exposures to macroeconomic sources of risk.

One issue of concern from an organizational and informational point of view is that exposure to macroeconomic uncertainty is not purely a financial issue. We have emphasized the exposure of commercial operations as one aspect of macroeconomic risk management. If the exposure of commercial operations can be taken as given and not considered an area of risk management, the CFO can take responsibility for management of all macroeconomic risk by estimating the exposure of commercial operations and take this exposure a benchmark for financial risk management.

Business areas, head of sales and head of purchasing may deal on their own with commercial cash flow exposures to macroeconomic variables, however. Investments in flexibility (real options) are often value increasing for these divisions. These real options create complexity from a risk management point of view. Since, real options tend to be value increasing if there is substantial macroeconomic uncertainty, it is desirable to have strong incentives to invest in flexibility. These investments affect commercial cash flow exposure and they create uncertainty about future cash flow exposures. These exposures will vary over time as a result of adjustments of business operations in response to changes in the macroeconomic environment. The exposure uncertainty makes the task of the CFO to measure and manage commercial cash flow exposure more complex.

One approach to the information problem created by investment in real options is to limit the CFO's responsibility to management of exposures of financial positions while the 
business divisions take responsibility for remaining exposures. In this case there is no one taking responsibility for overall exposure, however.

Another approach is to have the CFO responsible for total exposure while recognizing that measures of commercial exposure are uncertain as a result of real options. This uncertainty can managed to some extent by the use of financial options as hedging instruments.

A third approach is to combine the second approach with the creation of a centralized risk management group as envisioned by ERM and IRM. This group would not be directly responsible for operational risk management decisions but serve informational, coordinating and organizational roles. Risk management activities of the different parts of the firm would be coordinated and information flows among them would be made easier. The organizational roles would be to determine how and where to assign responsibilities for macroeconomic exposures, as well as to determine incentive schemes and performance evaluation.

\section{Conclusions}

In this chapter we have examined the information requirements for macroeconomic risk management within a comprehensive risk management strategy from a CFO's perspective. The strategic framework we developed is based on operational corporate objectives derived from the overall financial- and commercial strategies of a firm.

The choice of macroeconomic risk management strategy can be divided into two issues. One is the ability to adjust commercial operations and pricing to take advantage of profit opportunities by means of investments in real options. The second issue involves strategy choice when adjustability is low. In the latter case, the strategy can focus on adjustment of financial positions with the exposure of commercial operations as benchmark. We have proposed a set of risk management strategies for macroeconomic risk along with the information requirements within the finance function.

The strategy for using financial positions to reduce or offset the macroeconomic exposure of commercial operations can be viewed as a task for the CFO using information from the top level with respect to the general objectives of the firm and to acceptance of risk. The factors that determine a desirable strategy with respect to value or cash flows are time horizon, risk attitude and perceptions about efficiency of pricing in financial and goods markets. We show that if the CFO of a risk averse firm perceives that market's pricing makes 
it possible to beat the market, requirements on information systems are very high and possibly impossible to satisfy.

Evaluation and organization of risk management are important for incentives and information flows. The creation of a centralized risk management group as envisioned by ERM and IRM is particularly important in firms where risk is strongly affected by flexibility of business operations, since financial risk management is inseparable from decisions made with respect to business operations in this case.

\section{References}

Accenture (2007), "Chief Financial Officers and Chief Strategy Officers: Partners in Strategic Management", Accenture Institute for High Performance Business.

Amram, M. and Kulatilaka, N. (1999), Real Options: Managing Strategic Investment in an Uncertain World, Oxford University Press.

Capel, J. J. (1997), “A Real Option Approach to Economic Exposure Management”, Journal of International Financial Management and Accounting, Vol. 8, No. 2, p. 87-113.

Copeland, T. and Antikarov V. (2001), Real Option: A Practitioners Guide, Thomson Texere, New York.

CFO Research Services. (2002), "Strategic Risk Management: New Disciplines, New Opportunities", CFO Research Service and Aon.

CFO Research Services. (2005), “The CFO as Chief Performance Adviser”, CFO Research Services and PricewaterhouseCoopers LLP.

CFO Research Service. (2007), “The Superstar CFO, Optimizing an Increasingly Complex Role", CFO Research Service and SAP.

Froot, K. A., Scharfstein, D. S. and Stein, J. C. (1994), “A Framework for Risk Management”, Harvard Business Review, Vol. 16, No. 1, p. 145-165.

Hoyt, A. and Liebenberg, R. (2009), “The Value of Enterprise Risk Management”, Working Paper.

Kogut, B. and Kulatilaka, N. (1994), “Operating Flexibility, Global Manufacturing, and the Option Value of a Multinational Network”, Management Science 40, p. 123-139. 
Meulbroek, L. K. (2002), “A Senior Manager's Guide to Integrated Risk Management”, Journal of Applied Corporate Finance, Vol. 14, No. 4, p. 56-70.

Mian, S. (2001), "On the Choice and Replacement of Chief Financial Officers", Journal of Financial Economics, Vol. 60, p. 143-175.

Miller, K. D. (1992), “A Framework for Integrated Risk Management in International Business”, Journal of International Business Studies, Vol. 23, No. 2, p. 311-331.

Miller, K. D. (1998), "Economic Exposure and Integrated Risk Management”, Strategic Management Journal, Vol. 19, p. 497-514.

Nocco, B. W. and Stulz, R. M. (2006), "Enterprise Risk Management: Theory and Practice, Journal of Applied Corporate Finance, Vol. 17, No. 4, p. 8-20.

Oxelheim, L., Wihlborg, C. and Lim, D. (1990), "Contractual Price Rigidities and Exchange Rate Adjustments", International Trade Journal, Vol. 5, No. 2, p. 53-76.

Oxelheim, L. and Wihlborg, C. (2008), “Corporate Decision-Making with Macroeconomic Uncertainty", New York: Oxford University Press.

Shapiro, A. C. and Titman, S. (1986), “An Integrated Approach to Corporate Risk Management", in The Revolution in Corporate Finance. Boston: Blackwell.

Trigeorgis, L. (1996), Real Options: Managerial Flexibility and Strategy in Resource Allocation, MIT Press, Cambridge, MA. 